Savannah River

National Laboratory

OPERATEO BY SAVANNAH RIVER NUCLEAR SOLUTIONS

\title{
Analytical Results for MOX Colemanite Samples Received on July 22, 2013
}

Marissa M. Reigel and David R. Best

August 2013

SRNL-STI-2013-00470 
SRNL-STI-2013-00470

Revision 0

\section{DISCLAIMER}

This work was prepared under an agreement with and funded by the U.S. Government. Neither the U.S. Government or its employees, nor any of its contractors, subcontractors or their employees, makes any express or implied:

1. warranty or assumes any legal liability for the accuracy, completeness, or for the use or results of such use of any information, product, or process disclosed; or

2. representation that such use or results of such use would not infringe privately owned rights; or

3. endorsement or recommendation of any specifically identified commercial product, process, or service.

Any views and opinions of authors expressed in this work do not necessarily state or reflect those of the United States Government, or its contractors, or subcontractors.

\section{Printed in the United States of America}

Prepared for

U.S. Department of Energy 
Keywords: $M O X$

Colemanite

Boron

Retention: Permanent

\section{Analytical Results for MOX Colemanite Samples Received on July 22, 2013}

M. M. Reigel

D. R. Best

August 2013

Prepared for the U.S. Department of Energy under contract number DE-AC09-08SR22470.

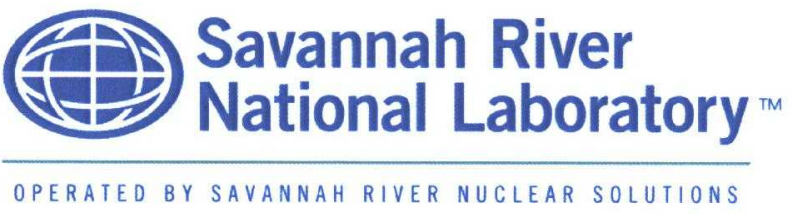




\section{REVIEWS AND APPROVALS}

AUTHORS:

M. M. Reigel, Engineering Process Development

Date

D. R. Best, Engineering Process Development

Date

TECHNICAL REVIEW:

A. D. Cozzi, Engineering Process Development per E7 2.60

Date

APPROVAL:

E. N Hoffman, Manager

Date

Engineering Process Development

S. L. Marra, Manager

Date

Environmental \& Chemical Process Technology Research Programs 
SRNL-STI-2013-00470

Revision 0

\section{EXECUTIVE SUMMARY}

The Mixed Oxide Fuel Fabrication Facility (MFFF) will use colemanite bearing concrete neutron absorber panels credited with attenuating neutron flux in the criticality design analyses and shielding operators from radiation. The Savannah River National Laboratory (SRNL) is tasked with measuring the boron oxide content of the colemanite raw aggregate material prior to it being mixed into the concrete. SRNL received ten samples of colemanite for analysis on July 22, 2013. The elemental boron content of each sample was measured according to ASTM C 1301. The boron oxide content was calculated using the oxide conversion factor for boron. 


\section{TABLE OF CONTENTS}

LIST OF TABLES

vii

LIST OF ABBREVIATIONS viii

1.0 Introduction

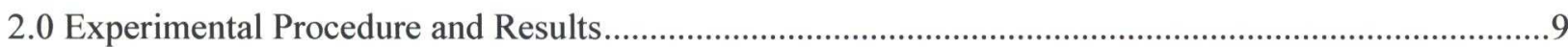

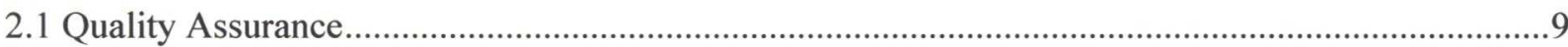

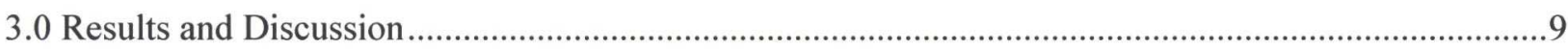

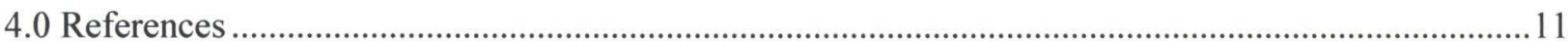


SRNL-STI-2013-00470

Revision 0

\section{LIST OF TABLES}

Table 1. Boron and Boron Oxide Content for MOX Colemanite Samples............................................... 10 


\section{LIST OF ABBREVIATIONS}

$\begin{array}{ll}\text { ASTM } & \text { American Society for Testing and Materials } \\ \text { ICP } & \text { Inductively Coupled Plasma } \\ \text { MFFF } & \text { Mixed Oxide Fuel Fabrication Facility } \\ \text { OES } & \text { Optical Emission Spectrometer } \\ \text { PSAL } & \text { Process Science Analytical Laboratory } \\ \text { SRNL } & \text { Savannah River National Laboratory }\end{array}$


SRNL-STI-2013-00470

Revision 0

\subsection{Introduction}

The Mixed Oxide Fuel Fabrication Facility (MFFF) will use colemanite bearing concrete neutron absorber panels credited with attenuating neutron flux in the criticality design analyses and shielding the operator from radiation. ${ }^{1}$ MOX services requires the boron oxide $\left(\mathrm{B}_{2} \mathrm{O}_{3}\right)$ content of the colemanite raw aggregate material to be determined prior to mixing and pouring of the sample concrete.

\subsection{Experimental Procedure and Results}

Ten samples of colemanite raw aggregate were delivered to Savannah River National Laboratory on July 22, 2013. Each sample weighed approximately one kilogram. Subsamples of the samples received on July 22, 2013 were ball milled, dried in an oven to remove moisture, and digested in triplicate using the ASTM method for trace metals analysis in limestone. ${ }^{2}$ Aliquots of each sample were weighed in separate beakers and then $10 \mathrm{ml}$ of $\mathrm{HCl}$ and $4 \mathrm{ml}$ of $\mathrm{HNO}_{3}$ were added. The acid mixture was heated at $95{ }^{\circ} \mathrm{C}$ for two hours in a beaker, with the sample covered with a watch glass. After heating was complete, the sample cooled for an additional 60 minutes to ensure complete boron dissolution. The sample was then diluted up to a final volume of $100 \mathrm{ml}$ with deionized water. The samples were analyzed on the Agilent 730 Inductively Coupled Plasma-Optical Emission Spectrometer (ICP-OES). Boron was calibrated using a High Purity NIST traceable standard (Lot 1204016), Appendix A: Boron Certificate of Analysis. An internal standard (yttrium) was used to compensate for matrix effects. The dissolution method prescribed in the ASTM method resulted in complete dissolution of the samples.

\subsection{Quality Assurance}

Requirements for performing reviews of technical reports and the extent of review are established in manual E7 2.60. SRNL documents the extent and type of review using the SRNL Technical Report Design Checklist contained in WSRC-IM-2002-00011, Rev. 2.

\subsection{Results and Discussion}

The digestion and analysis described in this report provides the elemental concentration of boron in the colemanite raw aggregate. An oxide conversion factor has to be applied to the raw data to calculate the concentration of boron oxide $\left(\mathrm{B}_{2} \mathrm{O}_{3}\right)$ in the colemanite. The oxide conversion factor for boron to $\mathrm{B}_{2} \mathrm{O}_{3}$ is 3.2199 . The elemental boron and boron oxide content for the ten colemanite samples are listed in Table 1. The average boron oxide content of the triplicate samples are also provided in Table 1. 
Table 1. Boron and Boron Oxide Content for MOX Colemanite Samples.

\begin{tabular}{|c|c|c|c|}
\hline Sample & $\begin{array}{c}\text { Elemental } \\
\text { Boron }(w t \%)\end{array}$ & $\begin{array}{l}\text { Boron Oxide } \\
\text { (wt \%) }\end{array}$ & $\begin{array}{c}\text { Average } \\
\mathrm{B}_{2} \mathrm{O}_{3} \\
(w t \%) \\
\end{array}$ \\
\hline Colemanite \#1 (A) & 13.1 & 42.2 & \multirow{3}{*}{41.8} \\
\hline Colemanite \#1 (B) & 13.1 & 42.2 & \\
\hline Colemanite \#1 (C) & 12.7 & 40.9 & \\
\hline Colemanite \#2 (A) & 12.8 & 41.2 & \multirow{3}{*}{41.1} \\
\hline Colemanite \#2 (B) & 12.8 & 41.2 & \\
\hline Colemanite \#2 (C) & 12.7 & 40.9 & \\
\hline Colemanite \#3 (A) & 12.2 & 39.3 & \multirow{3}{*}{39.7} \\
\hline Colemanite \#3 (B) & 12.1 & 39.0 & \\
\hline Colemanite \#3 (C) & 12.7 & 40.9 & \\
\hline Colemanite \#4 (A) & 12.3 & 39.6 & \multirow{3}{*}{39.8} \\
\hline Colemanite \#4 (B) & 12.2 & 39.3 & \\
\hline Colemanite \#4 (C) & 12.6 & 40.6 & \\
\hline Colemanite \#5 (A) & 13.4 & 43.1 & \multirow{3}{*}{41.9} \\
\hline Colemanite \#5 (B) & 12.7 & 40.9 & \\
\hline Colemanite \#5 (C) & 12.9 & 41.5 & \\
\hline Colemanite \#6 (A) & 12.2 & 39.3 & \multirow{3}{*}{39.4} \\
\hline Colemanite \#6 (B) & 12.3 & 39.6 & \\
\hline Colemanite \#6 (C) & 12.2 & 39.3 & \\
\hline Colemanite \#7 (A) & 14.1 & 45.4 & \multirow{3}{*}{43.6} \\
\hline Colemanite \#7 (B) & 13.4 & 43.1 & \\
\hline Colemanite \#7 (C) & 13.1 & 42.2 & \\
\hline Colemanite \#8 (A) & 13.2 & 42.5 & \multirow{3}{*}{42.6} \\
\hline Colemanite \#8 (B) & 13.5 & 43.5 & \\
\hline Colemanite \#8 (C) & 13.0 & 41.9 & \\
\hline Colemanite \#9 (A) & 13.2 & 42.5 & \multirow{3}{*}{40.6} \\
\hline Colemanite \#9 (B) & 12.5 & 40.2 & \\
\hline Colemanite \#9 (C) & 12.1 & 39.0 & \\
\hline Colemanite \#10 (A) & 13.3 & 42.8 & \multirow{3}{*}{43.3} \\
\hline Colemanite \#10 (B) & 13.6 & 43.8 & \\
\hline Colemanite \#10 (C) & 13.4 & 43.1 & \\
\hline
\end{tabular}




\subsection{References}

1. Wead, R., "Radiation Shielding and Fixed Neutron Absorber Panel Material and Inspection Requirements," DCS01-ZMJ-DS-SPE-M-19109-2, Revision 2, 2007.

2. "Major and Trace Elements in Limestone and Lime by Inductively Coupled PlasmaAtomic Emission Spectroscopy (ICP) and Atomic Absorption (AA)," ASTM International, ASTM C 1301-95 (reapproved 2009). 
SRNL-STI-2013-00470

Revision 0

Appendix A. Boron Certificate of Analysis

A-1 


\section{Certificate of Analpsis}

Product Description:

$\begin{array}{llll}\text { Name: } & \text { Boron } & \text { Source Material: } & \text { Boric Acid } \\ \text { Part Number: } & 10007-4 & \text { Material Purity: } & 99.999 \% \\ \text { Lot Number: } & 1204016 & \text { Matrix: } & \mathrm{H}_{2} \mathrm{O}\end{array}$

Certified Value:

$1000 \mu \mathrm{g} / \mathrm{mL} \pm 3 \mu \mathrm{g} / \mathrm{mL}$

The Certified value is based on gravimetric and volumetric preparation, and confirmed against SRM 3107 (lot number 070514 ) by inductively coupled plasma optical emission spectrometry (ICP-OES) using an internal laboratory-developed method. The uncertainty in the certified value is calculated for a $95 \%$ confidence interval and coverage factor $k$ is about 2 .

Density:

$1.000 \mathrm{~g} / \mathrm{mL} \pm 0.002 \mathrm{~g} / \mathrm{mL} @ 22.8^{\circ} \mathrm{C}$

\section{Uncertified Values:}

Titration Value: $\quad 994.97 \mu \mathrm{g} / \mathrm{mL}$

Trace Metal Impurity Scan: The data reported are based upon a scan of this specific lot at $1000 \mu \mathrm{g} / \mathrm{mL}$ via ICP analysis. The values are reported in $\mu \Omega / L$.

\begin{tabular}{|c|c|c|c|c|c|c|c|c|c|c|c|c|c|c|}
\hline $\mathrm{Ag}_{\mathrm{g}}$ & $<$ & 0.02 & $\mathrm{Cu}$ & $<$ & 0.1 & Li & $<$ & 1 & $\mathbf{R b}$ & $<$ & $0.0 ?$ & $\mathrm{Th}$ & $<$ & 0.02 \\
\hline $\mathrm{Al}$ & $<$ & 0.1 & Dy & $<$ & 0.02 & Lus & $<$ & 0.02 & Re & $<$ & 0.02 & $\pi$ & $<$ & 0.02 \\
\hline As & $<$ & 0.05 & $\mathrm{Ez}$ & $<$ & 0.02 & $\mathrm{Mg}$ & $<$ & 0.5 & $\mathbf{R h}$ & $<$ & 0.02 & $\mathrm{n}$ & $<$ & 0.02 \\
\hline $\mathrm{Au}$ & $<$ & 0.02 & Eu & $<$ & 0.02 & $\mathrm{Mn}$ & $<$ & 0.5 & Ru & $<$ & 0.02 & $\mathrm{Tm}$ & $<$ & 0.02 \\
\hline B & & $M$ & $\mathrm{Fe}$ & $<$ & 3 & Mo & $<$ & 0.02 & Sb & $<$ & 0.02 & $\mathbf{U}$ & $<$ & 0.1 \\
\hline Ba & $<$ & 0.1 & $\mathrm{Ga}$ & $<$ & 0.02 & $\mathrm{Na}$ & $<$ & 10 & $\mathrm{Se}$ & $<$ & 0.02 & $v$ & $<$ & 0.05 \\
\hline $\mathrm{Be}$ & $<$ & 0.02 & od & $<$ & 0.02 & $\mathrm{Nb}$ & $<$ & 0.02 & $\mathrm{Se}$ & $<$ & 0.1 & w & $<$ & 0.02 \\
\hline Bi & $<$ & 0.02 & $\mathrm{Ge}$ & $<$ & 0.02 & $\mathrm{Nd}$ & $<$ & 0.02 & $\mathbf{S i}$ & $<$ & 5 & $\mathbf{Y}$ & $<$ & 0.02 \\
\hline $\mathrm{Ca}$ & $<$ & 5 & $\mathrm{H} \ell$ & $<$ & 0.02 & $\mathrm{Ni}$ & $<$ & 0.02 & $\mathrm{Sm}$ & $<$ & 0.02 & $\mathrm{Yb}$ & $<$ & 0.02 \\
\hline $\mathrm{Cd}$ & $<$ & 0.02 & Ho & $<$ & 0.02 & Os & $<$ & 0.02 & $S_{n}$ & $<$ & 1 & $Z_{n}$ & $<$ & 0.1 \\
\hline $\mathrm{Ce}$ & $<$ & 0.02 & In & $<$ & 0.02 & $P b$ & $<$ & 0.05 & $\mathrm{St}$ & $<$ & 0.02 & $\mathbf{Z r}_{r}$ & $<$ & 0.02 \\
\hline Co & $<$ & 0.05 & Ir & $<$ & 0.02 & Pd & $<$ & 0.02 & $\mathrm{Ta}_{\mathrm{a}}$ & $<$ & 0.02 & & & \\
\hline $\mathrm{Cr}$ & $<$ & 0.1 & K & $<$ & 1 & Pr & $<$ & 0.02 & $\mathbf{T b}$ & $<$ & 0.08 & & & \\
\hline Cs & $<$ & 0.02 & La & $<$ & 0.02 & $\mathbf{P t}$ & $<$ & 0.02 & Te & $<$ & 0.02 & & & \\
\hline
\end{tabular}

Preparntion Information:

The standard solution is prepared using high purity materials and assayed by analytical methods for conformity prior to use. This standard was prepared using the methods developed at NIST for SRM Spectrometric Standard Solutions under appropriate laboratory conditions.

The matrix is 18 megaohm deionized wates.

Stability of this product is based upon rigorous short term and long term testing of the solution for the certified value. This testing includes, but is not limited to, the effect of temperature and packaging on the product.

Intended Use:

This Certified Reference Material (CRM) is intended for use as a calibration standard for the quantitative determination of boron, calibration of instruments such as ICPOES, ICPMS, AAS and XRF, and validation of analytical methods. It also can be used in EPA, ASTM and other methods.

Lot No: 1204016

Rev. Na: 5.00

Page 1 of 2 
Traceability Information:

The traceability of this standard is maintained through an unbroken chain of comparisons to appropriate standards with suitable procedure and measurement uncertainties. The mainternance of the base and derived units of International System of Units (SI) with traceability of measurement results (contempotary metrology)

to SI ensures their comparability over time as follows.

a. Standard Weight and Analytical Balance

The standard weights (NBS weights Inventory No 20231A) are calibrated every two years by South Carolina Metrology Laboratory that is a participant in "NIST Weights and Measures Measurement Assurance Program" with a certificate of measurement traceability to NIST primary standards.

The balances are calibrated yearly by the ISO 17025 accredited metrology service, and are verified weekly by an in-house method using standard weights.

b. Volumetric Device

The calibration of volumetric vessels is checked annuslly using the NBS 602 method.

c. Thermometer

The standard thermometers are calibrated every year by the ISO 17025 accredited metrology service. The thermometers used in-house are verified against the standard thermometers yearly.

d. Callbration Standards:

The Calibration Standard is directly traceable to SRM 3100 Series Spectrometric Standard Solutions.

Packaging and Storage Conditions:

The standard is packaged in a pre-cleaned polyethylene bottle. To maintain the integrity of this product, the solution should be kept tightly capped and stored under normal laboratory conditions.

\section{Refer to Material Safety Datasheet (MSDS) for harardous information.}

Expiration Information:

The expiry date is guaranteed to be valid for eighteen months from the shipping date provided. For this reason, standards from the same lot may have different expiration dates.
Preparation Date:
February 9, 2012
Shipped Date:
MAR 092012
Expiration Date:
SEP 092013

Certineate Issue Date: February 29, 2012

Quality Information:

(ACLASS

sSOMEC 17025:200s Accreditation Certifleate Number AT.1529

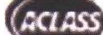

ISO Guide 34:2009 (RMP) Accreditation Certifieate Number AR-1436

$$
\text { Coing } 1 . y
$$

Vanay T. Yib,

Inorganic Laboratory Manager

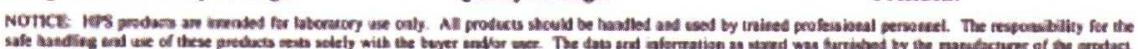

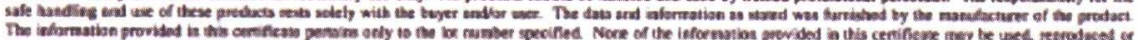

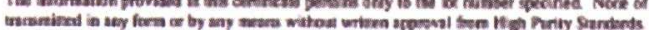

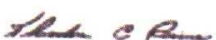

Theadere Rains, PhD

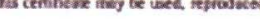

\section{Lot No.: 1204016 \\ Rev. Na.: 5.00 \\ Pues 2 of 2}




\section{Distribution:}

S. L. Marra, 773-A

T. B. Brown, 773-A

D. R. Click, 999-W

A. D. Cozzi, 999-W

W. A. Drown, 773-41

S. D. Fink, 773-A

C. C. Herman, 773-A

E. N. Hoffman, 999-W

F. M. Pennebaker, 773-42A

J.A. Spear, 235-11F

W. R. Wilmarth, 773-A

Records Administration (EDWS) 